\title{
Leucine Intake as Determinant of Muscle Strenght and Gait Speed in Elderly
}

\author{
Ratmawati $^{1^{*}}$, Siti Fatimah-Muis ${ }^{2}$, Muchlis Achsan Udji Sofro ${ }^{3,4}$ \\ ${ }^{1}$ Health Polytechnic Pangkalpinang, Pangkalpinang 33148, Indonesia \\ ${ }^{2}$ Department of Nutrition Science, Faculty of Medicine, Diponegoro University, \\ Semarang 50275, Indonesia \\ ${ }^{3}$ Department of Internal Medicine, Faculty of Medicine, Diponegoro University, \\ Semarang 50275, Indonesia \\ ${ }^{4}$ Central Public Hospital of Dr. Kariadi, Semarang 50244, Indonesia
}

\begin{abstract}
The purpose of this study was to analyse the intake of leucine as a determinant of muscle strength and gait speed in the elderly. This research is a cross-sectional study that involved 132 elderly people in the community (34 men and 98 women), aged 60-69 years. Data were obtained from interviews, physical examinations (body weight, body height, muscle mass, muscle strength, and gait speed), as well as food recall $3 \times 24$ hours. The statistical analysis employed Pearson's correlation coefficient and multiple linear regression. Intake of leucine was positively correlated with muscle strength $(\mathrm{r}=0.3 ; \mathrm{p}<0.001)$ and gait speed $(r=0.244 ; p<0.05)$. It was not intake of leucine that primarily determined muscle strength and gait speed but adequacy of energy intake.
\end{abstract}

Keywords: elderly, gait speed, leucine, muscle strength

\section{INTRODUCTION}

An elderly person, one aged 60 years or over, will experience a decline in muscle mass, muscle strength, and gait speed in a process known as the sarcopenia process. Sarcopenia, according to the European Working Group on Sarcopenia in the Older people (EWGSOP), is a syndrome caused by many factors resulting in decreased skeletal muscle mass, muscle strength, and physical function, with a risk of physical disability, diminished quality of life, increased risk of falls, effect on independency, as well as death (Naseeb \& Volpe 2017; Deutz et al. 2014; Cruz-Jentoft et al. 2010). The Asian Working Group for Sarcopenia (AWGS) states that the prevalence of sarcopenia in Asia ranges from $2.5 \%$ to $45.7 \%$ (Wu et al. 2016). The study by Vitriana et al. (2016) shows that, based on the AWGS recommended cut-off point, the prevalence of sarcopenia in the elderly (60-85 years of age) in Bandung and Jatinangor was 9.1\%, while based on the Taiwan population cut-off point, it was $40.6 \%$. This discrepancy occurred because there was no cut-off value spesifically determined for the elderly population in Indonesia.

Skeletal muscle mass is relatively constant from a young age to adulthood, with the increase in the amount of protein absorption being offset by the increase in the amount of catabolism during fasting. Elderly people with sarcopenia experience changes in the protein turnover, which affects the balance of the protein amounts (Kim et al. 2010). Muscle mass, muscle strength, and gait speed are indicators for the assessment of quality of life and independence in the elderly. Protein intake, especially leucine, is important for increasing the muscle mass, muscle strength, and physical function of the elderly. The Society on Sarcopenia, Cachexia, and Wasting Disorders recommends $1.0-1.5 \mathrm{~g}$ of protein $/ \mathrm{kg}$ body weight/ day, including the essential amino acid leucine (Naseeb \& Volpe 2017).

Essential amino acids are one of the amino acids needed by the body and can only come from food (Gropper \& Smith 2013). Branched-chain amino acids (BCAA), especially leucine, help regulate the muscle protein signaling pathway (Deutz et al. 2014). Leucine is one of the main essential amino acids to stimulate insulin from the pancreas, protect muscles, increase energy production, accelerate healing, and repair the skin (Gropper \& Smith 2013). The need for the amino acid leucine is higher (59 $\mathrm{mg}$ per $\mathrm{g}$ of protein per day) than that for other essential amino acids (WHO Report 2002). Food sources

"Corresponding Author: tel: +6281271032480 email: ummiranayumi@gmail.com 
of leucine include red meat, chicken, egg white, tuna, seaweed, and soybeans (Gropper \& Smith 2013).

Compared to young adults, the elderly consume fewer foods, including low energy and protein (Deutz et al. 2014; Kim et al. 2010). Based on the results of the Individual Food Consumption Survey in the Total Diet Study (Siswanto et al. 2014), the proportion of calorie and protein intake in elderly people aged $\geq 55$ years nationwide was low. It was $44.6 \%$ ( $<70 \%$ of RDA) for calories and $45.8 \%$ ( $<80 \%$ of RDA) for protein. The same was found by Triatmaja et al. (2013) who found that the average consumption of protein in the elderly population in Panti Werdha Bandung was $32 \mathrm{~g} /$ day, lower than that in the average Indonesian people (55.5 g/day). Meanwhile, Kobayashi et al. (2013) state that total protein intake $(74 \pm 14.3 \mathrm{~g} /$ day) was inversely correlated to the vulnerability of elderly women in Japan. Bauer et al. (2015) state that the administration of leucine-enriched whey protein for thirteen weeks can increase the muscle mass and lower the limb function in elderly community with sarcopenia.

Againts the backdrop above, this study aimed to analyse leucine intake as a determinant of muscle strength and gait speed. The results of this study will help set a basis for developing further epidemiological research in the prevention of sarcopenia.

\section{METHODS}

\section{Design, location, and time}

This observational study used a crosssectional design. The study was conducted in Girimaya Subdistrict, the working area of Girimaya Public Health Center, Pangkalpinang City, in October 2017-May 2018.

\section{Sampling}

The sample size was determined pourposively to represent all of the 5 (five) Integrated Development Posts in 5 (five) villages in Girimaya Subdistrict. Screening was performed on the potential study participants based on the inclusion and exclusion criteria, resulting in a total of 132 participants. The inclusion criteria were that the participants were elderly people aged 60-69 years, able to walk independently without tools, not staying in an elderly institution, able to grasp, and willing to participate in the study and to be cooperative. The exclusion criteria were that the participants were suffering from Alzheimer's disease, diabetes mellitus, severe cardiovascular, and/or muscle problems, and were undergoing hospitalization. The exclusion criteria were established based on the studies by Li et al. (2015) and Cruz-Jentoft et al. (2010), which state that chronic diseases, including organ failure, inflammatory factors, endocrine disease, diabetes, hypertension, arthritis, and osteoporosis, are associated with low muscle strength and physical performance.

Data were collected after approval was obtained from the Health Research Ethics Commission of the Faculty of Medicine of Diponegoro University with certificate number 19/EC/FK-RSDK/I/2018. Prior to data collection, each participant was asked for consent to the study procedures and signed the informed consent sheet.

\section{Data collection}

The independent variables were the intakes of leucine amino acid, protein, and energy, while the dependent variables were muscle mass, muscle strength, and gait speed.

Muscle mass measurement was performed by Bioelectrical Impedence Analysis (BIA), using the digital body fat monitor FEP-103 (Oserio). The calculation of the muscle mass index was performed by dividing the muscle mass in kilograms by the square of height in meters (muscle mass/height ${ }^{2}$ ); measurement of muscle strength was performed with Camry digital hand dynamometer (EH101), three times on the dominant hand in a standing position, the highest value taken; measurement of gait speed was performed for 6 minutes by the American Thoracic Society (ATS) procedures (ATS 2012; Li et al. 2013). Mileage was calculated based on the ability of the subject during that period to determine the gait speed in meters per second; analysis of food intake was carried out using the recall method $1 \times 24$ hours for 3 consecutive days by recording the types and amounts of food consumed over the past 24 hours.

The study used the BIA method because it is reliable and easy to use. Hand grip strength (HGS) is a gold standard and is easier to use in the study of the community. Meanwhile, gait speed was also chosen due to the ease of implementation (Naseeb \& Volpe 2017). The Taiwan population 
cut-off points were chosen as indicators due to the resemblance in anthropometric characteristics and life expectancy with those of the elderly in Indonesia in terms of ethnicity, genetics, body size, lifestyle, and cultural background. Therefore, the indicators for muscle mass assessment were $<8.87 \mathrm{~kg} / \mathrm{m}^{2}$ for men and $<6.42 \mathrm{~kg} / \mathrm{m}^{2}$ for women, the indicators for muscle strength assessment were $<22.5 \mathrm{~kg}$ for men and $<14.5 \mathrm{~kg}$ for women, and the indicator for gait speed of an elderly was $\leq 1 \mathrm{~m} / \mathrm{sec}$ (Vitriana et al. 2016; Chen et al. 2016; Chen et al. 2014).

\section{Data analysis}

All data were subjected to processing through editing, coding, and tabulation. Data on gender, age, body weight, body height, body mass index, muscle mass, muscle mass index, muscle strength, gait speed, protein, leucine, and energy intake were presented descriptively. It was followed by bivariate and multivariate analysis to measure the correlation between the independent and dependent variables as well as the diffrences between groups in the multivariate model. The bivariate analysis used the Pearson's correlation test with a significance value of $\mathrm{p}<0.05$. The multivariate analysis used multiple linear regression tests to test the variables; protein, leucine, and energy intake with a $\mathrm{p}$ value $<0.25$. The analysis were carried out using IBM SPSS Statistics version 21.

\section{RESULTS AND DISCUSSION}

The participants were elderly people in the community, aged 60-69 years with characteristics presented in Table 1. General description and the study variables are shown in Table 2.

Subject characteristics. The majority of the study participants were women (74.2\%). It is known that sex, is one of the factors that can influence muscle strength and physical performance in the elderly. The study of Zeng et al. (2016) shows that the decrease in gait speed among the elderly was more common in women $(40.69 \%)$ than in men $(28.67 \%)$, whereas the decreased in muscle strength was more common in men $(34.58 \%)$ than in women $(28.54 \%)$. The average age of the elderly was 63 years, with the lowest age being 60 years and the highest 69 years. Age is also one of the factors that can
Table 1. Characteristics of participants $(\mathrm{n}=132)$

\begin{tabular}{ccc}
\hline Variable & $\mathrm{n}$ & $\%$ \\
\hline Gender & 34 & 25.8 \\
Male & 98 & 74.2 \\
Female & & \\
Nutritional status $\left(\mathrm{BMI}^{*}\right)$ & 9 & 6.8 \\
Low $\left(<18.5 \mathrm{~kg} / \mathrm{m}^{2}\right)$ & 56 & 42.5 \\
Normal $\left(\geq 18.5-<24.9 \mathrm{~kg} / \mathrm{m}^{2}\right)$ & 67 & 50.7 \\
Obese $\left(\geq 25 \mathrm{~kg} / \mathrm{m}^{2}\right)$ &
\end{tabular}

affect muscle strength and physical performance in the elderly. Zeng et al. (2016) study states that the decreases in gait speed and muscle strength occurred after the age of 60 years in the elderly population in China. There are significant differences in muscle strength and gait speed based on age group.

General description and study variables. More than half of the participants were obese $(50.7 \%)$. Obesity and unstructured daily activities were associated with increased risk of lower gait speed with OR (95\% CI): 1.25 (1.09-1.43) and 2.77 (1.34-5.72) (Zeng et al. 2016). Obesity synergistically causes metabolic disorders and affects physical function, especially in the female elderly population in Asia (Wu et al. 2016). Obesity and sarcopenia are double burdens of health problem commonly found in the elderly who are less physically active, and further, this condition can lead to an increase in risk of insulin resistance, dyslipidemia, heart disease, and metabolic diseases (Bauer et al. 2015; Deutz et al. 2014; Naseeb \& Volpe 2017). The frequency distribution of assessment of sarcopenia can be seen in Table 3.

Muscle mass index. It was known that the mean of muscle mass and muscle mass index of the elderly were respectively $35.1 \mathrm{~kg}$ and $15.6 \mathrm{~kg} /$ $\mathrm{m}^{2}$ (see Table 2). The lowest muscle mass index was $10.07 \mathrm{~kg} / \mathrm{m}^{2}$, and the highest $20.20 \mathrm{~kg} / \mathrm{m}^{2}$, meaning that even the lowest value has exceeded the normal cut-off for the Taiwan population. The study by Vitriana et al. (2016) used the cutoff of the Taiwan population to determine the prevalence of sarcopenia in the elderly (60-85 years) in Bandung.

Table 3 describes that the muscle mass index of the elderly participating in this study was all in the moderate category $(100 \%)$, so the diagnosis of sarcopenia could not be established based on the cut-off for the Taiwanese population. The process of sarcopenia is characterized by 
Ratmawati et al.

Table 2. General description and study variables ( $\mathrm{n}=132$ people)

\begin{tabular}{lcccc}
\hline \multicolumn{1}{c}{ Variable } & Mean $\pm \mathrm{SD}$ & Median & Min-Max & $\mathrm{p}$ value \\
\hline Age (years) & - & 63 & $60-69$ & 0.000 \\
Weight $(\mathrm{kg})$ & $58.7 \pm 11.8$ & - & $28.2-92.1$ & 0.200 \\
Height $(\mathrm{m})$ & $1.5 \pm 0.1$ & - & $1.4-1.7$ & 0.062 \\
Body mass index $\left(\mathrm{kg} / \mathrm{m}^{2}\right)$ & $25.3 \pm 4.6$ & - & $13.6-37.9$ & 0.200 \\
Muscle mass $(\mathrm{kg})$ & - & 35.1 & $22.7-53.6$ & 0.000 \\
Muscle mass index $\left(\mathrm{kg} / \mathrm{m}^{2}\right)$ & $15.6 \pm 1.5$ & - & $10.1-20.2$ & 0.200 \\
Muscle strenght $(\mathrm{kg})$ & $19.6 \pm 7.3$ & - & $6.6-45.3$ & 0.060 \\
Gait speed $(\mathrm{m} / \mathrm{s})$ & $0.9 \pm 0.2$ & - & $0.3-1.5$ & 0.200 \\
Protein intake $(\mathrm{g})$ & $48.2 \pm 1.4$ & - & $23.6-88$. & 0.200 \\
Leucine intake $(\mathrm{mg})$ & $3,820 \pm 1,092$ & - & $1,866,7-7,200$ & 0.055 \\
Energy intake $(\mathrm{kcal})$ & $1.01 \pm 328$ & - & $678.6-2,273,2$ & 0.200 \\
\hline
\end{tabular}

SD: Standard deviation; Kolmogorov-Smirnov test; $\mathrm{p}$ value $>0.05$ (normally distributed)

a lack of muscle mass index, coupled with low muscle strength or low physical performance (Cruz-Jentoft et al. 2010). The normal muscle mass index found in the participants was thought to correlate with the energy and leucine amino acid intake.

However, in early 2018, the European Working Group on Sarcopenia in Older People (EWGSOP2) revised the diagnosis of sarcopenia with the aim of raising awareness of sarcopenia and risk factors as we get older. Sarcopenia identification focuses on low muscle strength as the main characteristic, then detects low muscle quantity and quality, and poor physical performance as an indication of severe sarcopenia. Based on EWGSOP2 recommendations, it was known that the prevalence of elderly sarcopenia based on the decrease of muscle strength was $29.6 \%$ ( $7.6 \%$ in men and $22 \%$ in women) (CruzJentoft et al. 2019).

Muscle strength. The average muscle strength of the elderly was $19.6 \mathrm{~kg}$. The study by Vitriana et al. (2016) used the cut-off of the Taiwan population to determine the prevalence of sarcopenia in the elderly (60-85 years) in Bandung. The criteria for elderly muscle strength in China are determined based on recommendations of the Asian Working Group for Sarcopenia (Zeng et al. 2016).

Based on the study by Vitriana et al. (2016), the main factors that influence the hand grip strength of the elderly are age, gender, total body fat, and fat-free mass. The factors age, gender, life style, and health status can affect the muscle strength of the elderly (Zeng et al. 2016). The study by Zeng et al. (2016) states that the correlation between muscle strength and physical performance varies according to age categories.

Gait speed. The average gait speed of the elderly was $0.9 \mathrm{~m} / \mathrm{sec}$. The study by Vitriana et al. (2016) used the cut-off of the Taiwan population to determine the prevalence of sarcopenia in the elderly (60-85 years) in Bandung. Zeng et al. (2016) used the recommendations of the Asian Working Group for Sarcopenia (AWGS) in determining the criteria for elderly gait speed in China.

Protein intake. The average protein intake of the elderly was $48.2 \mathrm{~g}$, which was lower than the national average of $61 \mathrm{~g}$ based on RDA 2013 (BKPM 2013). Hence, low protein intake is one of the risk factors for sarcopenia in the elderly (Deutz et al. 2014). Sarcopenia interventions can be done by consumption of foods high protein and exercising (Wu et al. 2016).

Leucine intake. The average leucine amino acid intake of the elderly was $3,820 \mathrm{mg}(3.8 \mathrm{~g})$ per day. The leucine source foods consumed by the elderly included: sea fish, white rice, bread/ cake, tempeh, tofu, eggs, chicken, meat and vegetables. The need for the amino acid leucine of the elderly was calculated as $39 \mathrm{mg} / \mathrm{kg}$ weight/ day. The World Health Organization (WHO) states that the estimated leucine requirement was $39 \mathrm{mg} / \mathrm{kg}$ per day or $59 \mathrm{mg} / \mathrm{g}$ of protein per day (Report of FAO/WHO/UNU 2002).

Energy intake. Energy intake was obtained from carbohydrates (rice, bread, tubers), proteins (sea fish, meat, chicken, eggs, tofu, tempeh), fats (oil, coconut milk), and vitamins (vegetables, fruits). Table 4 describes the correlation test of the amino acid leucine, protein, and energy intake to muscle strength and gait speed. 
Table 3. Frequency distribution of assessment of sarcopenia $(n=132)$

\begin{tabular}{lcccc}
\hline Assessment of sarcopenia & \multicolumn{2}{c}{ Male } & \multicolumn{2}{c}{ Female } \\
\cline { 2 - 6 } & $\mathrm{n}$ & $\%$ & $\mathrm{n}$ & $\%$ \\
\hline Muscle mass index $\left(\mathrm{kg} / \mathrm{m}^{2}\right)$ & & & & \\
$\quad$ Moderate/good (male: $\geq 8.87$; female: $\geq 6.42)$ & 34 & 25.8 & 98 & 74.2 \\
$\quad$ Less (male: $<8.87$; female: $<6.42)$ & 0 & 0 & 0 & 0 \\
Muscle strength (kg) & & & & \\
$\quad$ Moderate/good (male: $\geq 22.5$; female: $\geq 14.5)$ & 24 & 18.2 & 69 & 52.2 \\
$\quad$ Less (male: $<22.5 ;$ female: $<14.5)$ & 10 & 7.6 & 29 & 22 \\
Gait speed (m/s) & & & & \\
$\quad$ Moderate/good (male and female: $>1$ ) & 20 & 15.1 & 17 & 12.9 \\
$\quad$ Less (male and female: $\leq 1)$ & 14 & 10.6 & 81 & 61.4 \\
\hline
\end{tabular}

Leucine amino acid intake was positively correlated with muscle mass index $(p<0.05)$, muscle strength $(\mathrm{p}<0.001)$, and gait speed $(p<0.05)$. The elderly who had essential amino acid intake for 16 weeks experienced an increase in muscle mass and its function without any exercise intervention (Deutz et al. 2014). Proper nutrition intake, especially energy and protein, and physical activity have a role in the management of sarcopenia (Naseeb \& Volpe 2017; Kim et al. 2010; Arnold \& Bautmans 2014). Verhoeven et al. (2009) show that only long-term sources of leucine do not increase muscle mass or muscle strength.

Protein intake was positively correlated with muscle mass index $(\mathrm{p}<0.001)$, muscle strength $(p<0.001)$, and gait speed $(p<0.05)$ in the elderly in the community. The average protein intake of the elderly was $48.2 \mathrm{~g}$, which was lower than the national average of $61 \mathrm{~g}$ based on RDA 2013 (BKPM 2013). Deutz et al. (2014) state that when the daily protein intake cannot fulfill the increase in protein requirements of the elderly to maintain muscle function, negative nitrogen balance will occur and a decrease in protein levels, especially skeletal muscle protein happens. The habit of consuming the right amount of protein can reduce the loss of muscle function and inhibit the occurrence of sarcopenia in the elderly. Kobayashi et al. (2013) found that a total protein intake of $(74 \pm 14.3 \mathrm{~g} /$ day $)$ had a significant association with muscle susceptibility $(p<0.05)$, regardless of source and type of amino acid consumed. Tieland et al. (2012) assessed that the dietary intake of protein sources, daily protein distribution, and use of food sources containing protein (such as bread and milk) in community-dwelling $(\mathrm{n}=707)$, frail $(\mathrm{n}=194)$, and institutionalized $(\mathrm{n}=276)$ elderly people, could delay the occurrence of sarcopenia. Data of dietary intake of elderly people of living in the community, frail, and institutionalized in the Netherlands was collected based on the food records method for 2 to 3 days.

Energy intake was positively correlated with the sarcopenia process based on muscle mass index, muscle strength, and gait speed. The energy intake in the majority of the elderly was in the moderate category $(1,301 \mathrm{kcal})$ in $97.7 \%$ of subjects. Arnold and Bautmans (2014) state that proper nutritional intake, especially energy and protein, and physical activity had a role in sarcopenia management.

One of determine the relationship between nutritional intake and skeletal muscle mass is age. In addition, an increased skeletal muscle mass is associated with greater energy intake. Generally, men eat more sources of calories, so

Table 4. Correlation test of leucine amino acid, protein, and energy intake to muscle strength and gait speed in elderly people in community

\begin{tabular}{llllccc}
\hline \multirow{2}{*}{ Variable } & \multicolumn{2}{c}{ Muscle mass index } & \multicolumn{2}{c}{ Muscle strenght } & \multicolumn{2}{c}{ Gait speed } \\
\cline { 2 - 7 } & $\mathrm{p}$ value & $\mathrm{r}$ value & $\mathrm{p}$ value & $\mathrm{r}$ value & $\mathrm{p} \mathrm{value}$ & $\mathrm{r}$ value \\
\hline Leucine intake $^{\mathrm{a}}$ & $0.001^{*}$ & 0.299 & $0.000^{* *}$ & 0.31 & $0.005^{*}$ & 0.244 \\
Protein intake $^{\mathrm{b}}$ & $0.000^{* *}$ & 0.315 & $0.000^{* *}$ & 0.325 & $0.004^{*}$ & 0.251 \\
Energy intake $^{\mathrm{c}}$ & $0.000^{* *}$ & 0.375 & $0.000^{* *}$ & 0.351 & $0.003^{*}$ & 0.255 \\
\hline
\end{tabular}

a, b, c: Pearson's correlation coefficient; $p$ value $<0.001^{* *}$ : very significant; $p$ value $<0.05^{*}$ : significant; r value: direction of correlation (positive) 
there is a significant relationship between age and energy intake. Whereas in women less because it is influenced by patterns of age distribution and physiological changes (Jang \& Bu 2018). The multiple linear regression analysis of energy, leucine amino acid, and protein intake can be seen in Table 5.

Leucine intake was not the most influential factor in the muscle mass index, muscle strength, and gait speed of the elderly. The average leucine amino acid intake of the elderly was $3.8 \mathrm{~g}$ per day. However, the amount could still influence the effectiveness of amino acid functions in maintaining muscle mass, muscle strength, and gait speed of the elderly. Based on the study by Verhoeven et al. (2009), leucine supplementation of $7.5 \mathrm{~g}$ per day for 3 (three) months was not effective in increasing the muscle mass or muscle strength of healthy elderly men. Total protein intake according to adequacy needs to be considered because it is related to amino acids. During the 3 months be seen the impact of leucine supplementation on skeletal muscle mass, strength, and/or glycemic control in healthy elderly men. Leucine supplementation could increase the upper leg cross-sectional area and change the type composition of muscle fiber, but did not affect the whole-body's fat-free mass and glycemic control and/or blood lipid profile.

Maintaining mobility, physical function, and independence of the elderly is important to inhibit the development of sarcopenia (Bauer et al. 2015). Physical activity and combination of nutritional intake, especially protein and energy, based on the recommended dietary allowance (RDA) can increase muscle mass, and physical function, and achieve a balance of positive muscle protein (Naseeb \& Volpe 2017; Morley et al. 2010). The condition of sarcopenia or the risk factors for the cause of sarcopenia are not a barrier for the elderly to conduct physical activity (Liu et al. 2014).

Metabolic changes in the elderly cause less muscle protein synthesis despite the same amount of protein consumed by younger population (Morley et al. 2010). Protein food sources should be properly distributed, at a minimum of 25 to 30 $\mathrm{g}$ of high-quality protein per food item containing 2.5 to $2.8 \mathrm{~g}$ of leucine to stimulate muscle protein synthesis for the blunted sensitivity of older muscles to low doses of amino acids (Bauer et al. 2015). The quantity, quality, and time of protein intake are important factors for maintaining muscle mass and function (Bauer et al. 2015; Tieland et al. 2012).

The muscle mass and muscle strength in the elderly can be increased by intake high protein. Protein consumption of $1.1 \mathrm{~g} / \mathrm{kgW} /$ day can affect lean body mass (LBM) stronger than protein consumption of $0.7-0.9 \mathrm{~g} / \mathrm{kgW} /$ day. Protein intake between 1.1 and $1.6 \mathrm{~g} /$ $\mathrm{kgW} /$ day is needed to achieve nitrogen balance (Deutz et al. 2014). The consumption of whey protein can increase muscle protein synthesis better than casein. Whey protein intake contains enough leucine amino acids in protein synthesis to maintain muscle mass and function in the elderly with sarcopenia (Bauer et al. 2015). The

Table 5. Anylsis of multiple linear regression analysis of energy, leucine amino acid, and protein intake on muscle mass index, muscle strength, and gait speed

\begin{tabular}{cccccc}
\hline Variable & $\begin{array}{c}\text { Constant } \\
\text { value }\end{array}$ & $\begin{array}{c}\text { Regression } \\
\text { coefficient }\end{array}$ & $\begin{array}{c}\text { Correlation } \\
\text { coefficient }\end{array}$ & $\begin{array}{c}\text { Anova } \\
\text { test }\end{array}$ & $\begin{array}{c}\text { Adj R } \\
\text { square }\end{array}$ \\
\hline $\begin{array}{c}\text { Muscle mass index } \\
\text { Leucine intake }\end{array}$ & - & - & - & - & - \\
$\begin{array}{c}\text { Protein intake } \\
\text { Energy intake }\end{array}$ & - & - & - & - & - \\
Muscle strength & 13.358 & 0.002 & 0.372 & 0.000 & 0.132 \\
Leucine intake & - & - & - & - & - \\
$\begin{array}{c}\text { Protein intake } \\
\text { Energy intake }\end{array}$ & - & - & - & - & - \\
Gait speed & 8.819 & 0.007 & 0.318 & 0.000 & 0.162 \\
Leucine intake & - & - & - & - & - \\
Protein intake & - & - & - & - & - \\
Energy intake & 0.747 & 0.0001 & 0.239 & 0.000 & 0.195 \\
\hline
\end{tabular}

a: Variable that appeared at the end of the multiple linear regression test 
pattern of protein intake which varies in 4 times of administration can stimulate protein synthesis in the elderly, which is affected by differences in age and exercise. Bollwein et al. showed that the amount of protein intake was not associated with frailty, but the distribution in the morning, afternoon, and evening in a way was associated with vulnerability (Kobayashi et al. 2013).

\section{CONCLUSION}

Protein and leucine amino acid intakes were positively correlated with muscle mass index, muscle strength, and gait speed in the elderly in the community. Leucine food intake was not a major determinant for muscle mass, muscle strength, and gait speed. Energy intake was the most influential factor in muscle mass, muscle strength, and gait speed. The elderly in the community are expected to increase food intake of energy, protein, and leucine amino acid to increase muscle mass, muscle strength, and gait speed.

\section{ACKNOWLEDGEMENT}

Thanks are due to BPPSDM of Ministry of Health of the Republic of Indonesia for the fund provided based on the Decree of the Minister of Health of the Republic of Indonesia Number HK.02.02/H.V/SK/169/2016 on Participants of Study on Health Human Resources and Assistance for Study in 2016, as well as nutrition workers and cadres at the Girimaya Community Health Center in Pangkalpinang City. The authors have no conflict of interest.

\section{REFERENCES}

[ATS] American Thoracic Society. 2002. ATS Statement: guidelines for the sixminute walk test. Am J Respir Crit Care Med 166(1):111-117. DOI: 10.1164/ recm.166/1/111.

Arnold P, Bautmans I. 2014. The influence of strength training on muscle activation in elderly persons: A systematic review and meta-analysis. Exp Gerontol 58:58-68. http://dx.doi.org/10.1016/j. exger.2014.07.012.

[BKPM] Badan Koordinasi Penanaman Modal. 2013. Angka kecukupan gizi yang dianjurkan bagi bangsa Indonesia. https:// peraturan.bkpm.go.id/jdih/userfiles/ batang/PMK\%20No.\%2075\%20ttg\%20 Angka\%20Kecukupan\%20Gizi\%20 Bangsa\%20Indonesia.pdf. [Accessed 20 March 2014].

Bauer JM, Verlaan S, Bautmans I, Brandt K, Donini LM, Maggio M, McMurdo MET, Mets T, Seal C, Wijers SL, et al. 2015. Effects of a vitamin D and leucine-enriched whey protein nutritional supplement on measures of sarcopenia in older adults, the Provide Study: A randomized, doubleblind, placebo-controlled trial. Journal Jamda 16(9):740-747. http://dx.doi. org/10.1016/j.jamda.2015.05.021.

Chen LK, Lee WJ, Peng LN, Liu LK, Arai H, Akishita M, Asian Working Group for Sarcopenia. 2016. Recent advances in sarcopenia research in Asia: 2016 update from the Asian working group for sarcopenia. Jamda 17(8):767e1767e7. https://doi.org/10.1016/j. jamda.2016.05.016.

Chen LK, Liu LK, Woo J, Assantachai P, Auyeung TW, Bahyah KS, Chou MY, Chen LY, Hsu PS, Krairit O, et al. 2014. Sarcopenia in Asia: Consensus report of the Asian Working Group for Sarcopenia. Jamda 15(2):95-101. doi: 10.1016/j. jamda.2013.11.025.

Cruz-Jentoft AJ, Baeyens JP, Bauer JM, Boirie Y, Cederholm T, Landi F, Martin FC, Michel JP, Rolland Y, Schneider SM, et al. 2010. Sarcopenia: European consensus on definition and diagnosis: Report of the European working group on sarcopenia in older people. Age and ageing 39(4):412423. doi: 10.1093/ageing/afq034.

Deutz NEP, Bauer JM, Barazzoni R, Biolo G, Boirie Y, Bosy-Westphal A, Cederholm T, Cruz-Jentoft A, Krznaric Z, Nair KS, et al. 2014. Protein intake and exercise for optimal muscle function with aging: Recommendations from the ESPEN expert group. Clinical Nutrition 33(6):929936. http://dx.doi.org/10.1016/j. clnu.2014.04.007.

Gropper SS, Smith JL. 2013. Advanced nutrition and human metabolism. Sixth Edition. USA: Yolanda Cossio.

Jang BY, Bu SY. 2018. Total energy intake according to the level of skeletal muscle mass in Korean adults aged 30 years 
and older: An analysis of the Korean national health and nutrition examination surveys (KNHANES) 2008-2011. Nutr Res Pract 12(3):222-232. doi:10.4162/ nrp.2018.12.3.222.

Kim JS, Wilson JM, Lee SR. 2010. Dietary implications on mechanisms of sarcopenia: Roles of protein, amino acids and antioxidants (reviews). J Nutr Biochem 21(1):1-13. doi:10.1016/j. jnutbio.2009.06.014.

Kobayashi S, Asakura K, Suga H, Sasaki S. 2013. High protein intake is associated with low prevalence of frailty among old Japanese women: A multicenter cross-sectional study. Nutr J 12:164.

Li CI, Li TC, Lin WY, Liu CS, Hsu CC, Hsiung $\mathrm{CA}$, Chen $\mathrm{CY}$, Huang $\mathrm{KC}$, Wu $\mathrm{CH}$, Wang CY, et al. 2015. Combined association of chronic disease and low skeletal muscle mass with physical performance in older adults in the sarcopenia and translational aging research in Taiwan (START) study. BMC Geriatrics 15:11. DOI 10.1186/ s12877-015-0011-6.

Liu CK, Leng X, Hsu FC, Kritchevsky SB, Ding J, Earnest CP, Ferrucci L, Goodpaster BH, Guralnik JM, Lenchik L, et al. 2014. The impact of sarcopenia on a physical activity intervention: the lifestyle interventions and independence for elders pilot study (LIFE-P). J Nutr Health Aging 18(1):5964. doi:10.1007/s12603-013-0369-0.

Liu LK, Lee WJ, Liu CL, Chen LY, Lin MH, Peng LN, Chen LK. 2013. Age-related skeletal muscle mass loss and physical performance in Taiwan: Implications to diagnostic strategy of sarcopenia in Asia. Geriatr Gerontol Int 13(4):964-971. https://doi.org/10.1111/ggi.12040.

Morley JE, Argiles JM, Evans WJ, Bhasin S, Cella D, Deutz NEP, Doehner W, Fearon $\mathrm{KCH}$, Ferrucci L, Hellerstein MK, et al. 2010. Nutritional recommendations for the management of sarcopenia. Jamda 11(6):391-396. doi:10.1016/j.jamda. 2010.04.014.

Naseeb MA, Volpe SL. 2017. Protein and exercise in the prevention of sarcopenia and aging. Nutr Res 4:1-20 doi:10.1016/j. nutres.2017.01.001.
Report of a joint FAO/WHO/UNU expert consultation. Protein and amino acid requirements in human nutrition. 2002; WHO technical report series; 935. Geneva, Switzerland. p. 135-151.

Siswanto, et al. 2014. Studi Diet Total: Survei Konsumsi Makanan Individu Indonesia 2014, edisi pertama. Jakarta: Lembaga Penerbitan Badan Penelitian dan Pengembangan Kesehatan Kemenkes.

Tieland M, Berg KJBVD, Loon LJCV, De Groot LCPGM. 2012. Dietary protein intake in community-dwelling, frail, and institutionalized elderly people: Scope for improvement. Eur J Nutr 51(2):173-179. doi:10.1007/ s00394-011-0203-6.

Triatmaja NT, Khomsan A, Dewi M. 2013. Asupan kalsium, status gizi, tekanan darah dan hubungannya dengan keluhan sendi lansia di panti werdha Bandung. Jurnal Gizi dan Pangan 8(1): 25-32. DOI: https:// doi.org/10.25182/jgp.2013.8.1.25-32.

Vitriana, Defi IR, Nugraha GI, Setiabudiawan B. 2016. Prevalensi sarkopenia pada lansia di komunitas (community dwelling) berdasarkan dua nilai cut-off parameter diagnosis. MKB 48(3): 164-170. https:// doi.org/10.15395/mkb.v48n3.417.

Verhoeven S, Vanschoonbeek K, Verdijk LB, Koopman R, Wodzig WK, Dendale P, Loon LJCV. 2009. Long-term leucine supplementation does not increase muscle mass or strength in healthy elderly men. Am J Clin Nutr 89(5):1468-1475. https:// doi.org/10.3945/ajen.2008.26668

Wu YH, Hwang AC, Liu LK, Peng LN, Chen LK. 2016. Sex differences of sarcopenia in Asian populations: The implications in diagnosis and management. J Clin Gerontol Geriatr 7(2):37-43.

Yu SCY, Khow KSF, Jadczak AD, Visvanathan R. 2016. Clinicalscreening tools for sarcopenia and its management, review article. Curr Gerontol Geriatr Res 2016:1-10. http:// dx.doi.org/10.1155/2016/5978523.

Zeng P, Han Y, Pang J, Wu S, Gong H, Zhu J, Li J, Zhang T. 2016. Sarcopenia-related features and factors associated with lower muscle strength and physical performance in older Chinese: A cross sectional study. BMC Geriatrics 16(1):45 DOI 10.1186/ s12877-016-0220-7. 